\title{
Notes
}

\section{Is Prosecution a Core Executive Function? Morrison v. Olson and the Framers' Intent}

\author{
Stephanie A.J. Dangel
}

With stinging rhetoric, Justice Antonin Scalia accused the majority in Morrison $v$. Olson ${ }^{1}$ of sanctifying the office of special prosecutor by sacrificing the separation of powers doctrine and the individual liberty this constitutional principle was designed to protect. Despite the Act's insulation of the independent counsel from presidential control, ${ }^{2}$ the Morrison majority held that the Ethics in Government Act of 1978 did not "impermissibly interfere with the President's authority under Article II in violation of the constitutional principle of separation of powers."3 Isolated in dissent, Justice Scalia no longer stands alone in criticizing the malleability of the majority's "impermissible interference" standard:" How will the

1. 108 S. Ct. 2597 (1988).

2. The Ethics in Government Act provides for the appointment of an "independent counsel" to investigate and, if appropriate, prosecute certain high ranking government officials for violations of federal criminal laws. Upon receipt of information alleging such a violation, the Attorney General has ninety days to make an unreviewable decision as to whether an independent counsel should be appointed. If the Attorney General decides an independent counsel is warranted, the Special Division of the D.C. Circuit appoints the independent counsel and sets her jurisdiction on the basis of information provided by the Attorney General. The Special Division also has certain ministerial functions, such as receipt of reports, and can terminate the counsel's office when the task is complete. The independent counsel can exercise all the investigative and prosecutorial powers of the Department of Justice and the Attorney General, subject only to good cause removal by the Attorney General. See The Ethics in Government Act of 1978, 28 U.S.C. $\$ \S 49,591-99$ (Supp. V 1987).

3. $108 \mathrm{~S}$. C.t. at 2602 (emphasis added).

4. See, e.g., Carter, The Independent Counsel Mess, 102 Harv. L. Rev. 105 (1988); Liberman, Morrison v. Olson: A Formalistic Perspective on Why the Court Was Wrong, 38 AM. U.L. REv. 313 
President know when future legislation "impermissibly interferes" with his authority? The dissenter sarcastically characterizes the majority's response to the Chief Executive: "Trust us. We will make sure that you are able to accomplish your constitutional role.' I think the Constitution gives the President-and the people-more protection than that."

Morrison does give more protection than that. The fundamental guidepost to the opinion's protective force lies in the majority's conclusion on the executive nature of prosecution: The Morrison majority determined that the prosecutorial functions performed by the independent counsel are not quintessentially executive in nature, but are executive only in the sense that they are functions "that typically have been undertaken by officials within the Executive Branch." "When viewed without context, this distinction adds "nothing but atmosphere" - when viewed against the backdrop provided by the history of prosecution from a separation of powers perspective, Morrison's distinction yields an important test to guide future separation of powers decisions. This Note begins exploration of this history by asking whether the Framers intended prosecution to be a core executive function. ${ }^{8}$

An analysis of the Framers' writings within their historical context shows that the Framers did not intend prosecution to be a core executive function - in fact, they intended that prosecution be executive in the same sense as the Morrison conclusion. First, the Framers intended that prosecution would be undertaken by, not constitutionally assigned to, executive officials. Second, the Framers intended that executive officials would typically, not always, prosecute. Third, the Framers intended that prosecution would be an executive, but not necessarily a presidential, function. Hence, they provided that most prosecution would be undertaken by officials within the executive branch, but not necessarily executive officials subject to presidential control through appointment, direction, and removal. ${ }^{9}$

(1989); cf. Gewirtz, Realism in Separation of Powers Thinking, 30 WM. \& MaRY L. Rev. 343, 351-54 (1989) (Morrison should be read narrowly in light of its factual circumstances).

5. 108 S. Ct. at 2637 (Scalia, J., dissenting).

6. Id. at 2619 (emphasis added).

7. Id. at 2626 (Scalia, J., dissenting).

8. More specifically, this Note will ask whether the Framers would have opposed the Morrison majority's conclusion on the executive nature of prosecution and their resulting decision to uphold prosecution as it occurs under the Ethics in Government Act.

The Supreme Court has often looked to the Framers' intent on questions of governmental structure. In the early twentieth century, the majorities in Myers v. United States, 272 U.S. 52 (1926), and Humphrey's Executor v. United States, 295 U.S. 602 (1935)-which disagreed on the constitutionality of limits on presidential removal - concurred on the importance of the Framers' intent. The Morrison Court shows similar agreement on the significance of original intent: The Morrison majority invokes Justice Scalia's Framers for the appointment clause question addressed in Part I. See $108 \mathrm{~S}$. Ct. at 2610-11.

9. The Morrison majority asked whether the Ethics in Government Act impermissibly interfered with the President's authority under Article Two, not the authority of the executive branch in general. $108 \mathrm{~S}$. Ct. at 2616 . Thus, throughout this Note, "core executive" will be used interchangeably with "presidential" to refer to prosecution subject to presidential control through appointment, direction and removal. 
Discerning the Framers' intent on the executive nature of prosecution proves a challenging task: The Constitution contains no mention of the function, and the Framers never directly consider it in either their debates or correspondence. To divine the Framers' intent, Part I of this Note depicts the model of colonial criminal prosecution that the Framers carried with them to the Constitutional Convention. Part II then explores the Framing by examining the relevant constitutional provisions and the debates behind them. Finally, Part III examines early federal practice to uncover the Framers' intentions as they were forced to elaborate their constitutional system. This analysis of the Framers' writings within their historical context reveals that Morrison provides an objective and historically grounded test. ${ }^{10}$

\section{The Colonial Heritage}

The history of colonial prosecution exhibits four characteristics in conflict with the assertion that prosecution is a core executive, or presidential, function. First, private individuals, not government officials, conducted the bulk of prosecution. Second, the primary work of attorneys general and district attorneys consisted of non-prosecutorial duties, with their prosecutorial discretion limited to ending, rather than initiating or conducting, prosecutions. Third, public prosecution was locally based, not centrally controlled. Fourth, colonial and state constitutions did not classify prosecution as the exclusive province of any one branch.

\section{A. The Prevalence of Private Prosecution}

Seventeenth and eighteenth century English common law viewed a crime as a wrong inflicted upon the victim, not as an act against the state. ${ }^{11}$ An aggrieved victim, or interested party, would initiate prosecution. After investigation and approval by a justice of the peace and grand jury, a private individual would conduct the prosecution, sometimes with assistance of counsel. ${ }^{12}$

10. While this Note will elucidate an historical basis for the majority's conclusion on the executive nature of prosecution, it does not explain why the majority settled for their unelaborated conclusion. The majority may have compromised on this ambiguous concession in order to achieve the unanimity evident in executive power cases such as United States v. Nixon, 418 U.S. 683 (1974), and Dames \& Moore v. Regan, 453 U.S. 654 (1981). The ambiguity of the majority's unelaborated conclusion could conceal a number of factions. The majority may have disagreed on the conclusiveness of the historical analyses. Although a number of briefs presented useful historical perspectives, e.g., Brief Amicus Curiae of Whitney North Seymour, Jr., Appendix, Morrison v. Olson, 108 S. Gt. 2597 (1988) (No. 87-1249), surprisingly no comprehensive history of prosecution from a separation of powers perspective exists. Alternatively, the more pro-executive Justices in the majority may have refused to join an opinion based on an historically circumscribed notion of executive power. Finally, a more forceful conclusion would have starkly contrasted with Justice White's repeated references to prosecution as the one, true "executive" function. See, e.g., INS v. Chadha, 462 U.S. 919, 1002 (1983) (White, J., dissenting).

11. See 3 W. Blackstone, Commentaries *160.

12. See J. Tobias, Crime and Police in England 1700-1900, at 117-19, 128-31 (1979); 
While American colonial statutes appear to have vested public "prosecutors" with more prosecutorial responsibility than their English ancestors, ${ }^{13}$ recent studies focusing on prosecutorial practice show the persistence of a primarily private system of colonial prosecution. ${ }^{14}$ Many of the crimes today viewed as related to property (e.g., cases involving theft of goods in trade or destruction of land improvements or crops) were civil actions, and thus prosecuted privately. ${ }^{15}$ Even in the smaller category of colonial criminal cases, justices of the peace or aldermen summarily handled their caseload of privately initiated prosecutions with informal procedures. ${ }^{16}$ Private parties retained ultimate control, often settling even after grand juries returned indictments. ${ }^{17}$

Contemporaneous sources confirm the relative insignificance of public prosecutors in the colonial criminal system. Only five of the first thirteen constitutions mention a state attorney general, and only Connecticut mentions the local prosecutor. ${ }^{18}$ Secondary references are similarly rare. ${ }^{18}$ Finally, the earliest judicial decision voicing disapproval of private prosecution did not appear until $1849 .{ }^{20}$ No decision affirming public prosecutors' virtually unreviewable discretion appeared before $1883 .^{21}$

Baker, Criminal Courts and Procedure at Common Law, in CRImE IN ENGLAND 1550-1800, at 15-20 (J.S. Cockburn ed. 1977).

13. For example, from 1704 the Queen's attorney in Connecticut was to "prosecute and implead in the lawe all criminall offenders, and to doe all other things necessary or convenient as an atturney to suppresse vice and imorallitie." C. HoAdiy, 4 The Public Records of the Colony of ConNECTICUT 468 (Hartford 1868). The attorney general in New Hampshire, first appointed in 1683, was to present criminal indictments before the grand jury. E. PAGE, Judicial BeginNings iN NEw HAMPSHIRE 60 (1959).

14. For a summary of these studies, see Steinberg, From Private Prosecution to Plea Bargaining: Criminal Prosecution, the District Attorney, and American Legal History, 30 CRIME \& DelinQ. $568,571-72$ (1984). Steinberg's break from previous scholarship emphasizing colonial public prosecution, see, e.g., J. Kress, Progress and Prosecution, 423 AnNals 99, 103 (1976), followed from his shift in sources. Early studies concentrating on legislation naturally over-emphasized the importance of the public prosecutor, since a private prosecution system inherited from English common law would not appear in legislation. Examinations of prosecutorial practice were cursory and thus skewed. The most readily accessible information relating to criminal prosecution predictably concerned the exceptional, well-publicized cases conducted by public prosecutors, not the vast majority of mundane cases, involving scant paperwork and handled through the simple procedures of private prosecution. In contrast, Steinberg focused intensively on prosecutorial practice. Cf. Steinberg, supra, at 569 .

15. See Gaskins, Changes in the Criminal Law in Eighteenth-Century Connecticut, 25 AM. J. LEgal Hist. 309, 313-15 (1981).

16. See, e.g., J. Goebel \& T. Naughton, Law Enforcement in Colonial New York 341, 347-50, 366-67, 379-82 (1944); Steinberg, supra note 14, at 572-73.

17. See, e.g., Spindel, The Administration of Criminal Justice in North Carolina, 1720-40, 25 AM. J. Legal Hist. 141, 161 (1981) (in North Carolina, courts dismissed over half of cases because private parties settled); Steinberg, supra note 14, at 574 (in Pennsylvania, private control persisted into nineteenth century).

18. J. Jacoby, The American Prosecutor: A Search for Identity 22 (1980).

19. Jacoby found few written references to the prosecutor even in the period immediately after 1789. See id. at 273. An 1816 manual for bar members describing New York government covers 21 officers without mentioning public prosecutors. J. Tappen, THE CountY and Town Offices (Kingston, N.Y. 1816).

20. Commonwealth v. Williams, 56 Mass. (2 Cush.) 582 (1849).

21. People v. Wabash, St. L. \& Pac. Ry., 12 Ill. App. 263 (1883). 


\section{B. The Work of Public "Prosecutors"}

The work of colonial public "prosecutors" resembled that of their English counterparts in four respects. First, colonial attorneys general and district attorneys performed non-prosecutorial tasks: Attorneys general provided opinions and advice to governors, councils, legislatures, and courts, while local public prosecutors handled land transfers and patent applications. ${ }^{22}$ Second, while colonial public prosecutors conducted most cases that directly infringed the state's interests, ${ }^{28}$ private individuals at times prosecuted even "great public wrongs." 24 Third, public prosecutors performed the administrative tasks of a quasi-judicial official or adjunct to the court. ${ }^{25}$ Finally, the only discretionary prosecutorial task exercised by public officials in common criminal cases was the decision to end, rather than to initiate or conduct, prosecutions. Yet colonial prosecutors confined even this power to cases of malicious prosecution and misdemeanors where the parties consented. ${ }^{28}$ As will be seen in later sections, the power to end prosecutions and the advisory role of the attorney general remained the most consistent tasks of public "prosecutors."

\section{Centralized versus Local Prosecution}

As population dispersed and crime increased, the colonies established county courts with original jurisdiction. ${ }^{27}$ With this reform, public prosecution shifted from an initially centralized to a more locally based function. Beginning in 1704, Connecticut county courts appointed local public prosecutors. ${ }^{28}$ By 1711 , Virginia county courts were nominating local men to serve as deputy attorneys general. ${ }^{2 \theta}$ After 1732 , New York counties paid deputy attorneys general, many of whom settled in the counties and

22. See Cooley, Predecessors of the Federal Attorney General: The Attorney General in England and the American Colonies, 2 AM. J. Legal Hist. 304, 307-12 (1958).

23. Goldstein, History of the Public Prosecutor, in EnCyclopedia of Crime ANd Justice 1286 (Kadish ed. 1983). Moreover, the number of "public" crimes was still relatively small, although increasing. See generally Nelson, Emerging Notions of Modern Criminal Law in the Revolutionary Era: An Historical Perspective, 42 N.Y.U. L. Rev. 450 (1967).

24. See, e.g., Rutgers v. Waddington, Select Cases of the Mayor's Court of New York Crry, 1674-1784, at 57-59, 302-27 (R. Morris ed. 1935) (in 1783, victim used private prosecution for trespass to vindicate anti-Tory state policy in derogation of Sixth Article of the Treaty of Peace).

25. The public prosecutor either acted as a clerk or simply placed the private prosecutor on the stand and let him state his case before instructing the defense to do the same. See J. JACOBY, supra note 18, at 22-24; Steinberg, supra note 14 , at 577 .

26. See id. at $576-77,583$. The power to end prosecutions, unlike the power to initiate or conduct them, rested on a strong historical foundation. The attorney general of England played an occasional role in curbing the excesses of private prosecution. By filing a writ of nolle prosequi (indicating his intention not to prosecute), the attorney general could dismiss any prosecution. See A. GoldSTEIN, The Passive Judiciary: Prosecutorial. Discretion and the Guilty Plea 12 (1981).

27. In 1691 , New York became the first colony to establish such a system, followed by Maryland and Massachusetts in 1692, Pennsylvania in 1702, Connecticut in 1704, Virginia in 1705 and South Carolina in 1721 . J. JACOBY, supra note 18 , at 11-17.

28. See supra note 13.

29. See O. Chitwood, Justice in Colonial Virginia 120 (1905). 
became local bar members. ${ }^{30}$ This cooptation of nominally state officers by local government continued after 1789 as state constitutions separated local prosecutors from the attorney general, ${ }^{31}$ culminating in the 1830 's with the local election of public prosecutors. ${ }^{32}$ This trend toward prosecution as a locally based function cuts against the notion of centralized executive control.

\section{Executive, Judicial, and Legislative Prosecution}

The previous sections have shown the prevalence of a private prosecution system assisted by minor, local officials. Given these conclusions, it is not surprising to discover that most state constitutions at the time of the Framing did not mention, let alone classify, the prosecutorial function. Five state constitutions included the office of attorney general under the judicial article. ${ }^{33}$ However, state attorneys general acted primarily as legal advisors, not prosecutors. ${ }^{34}$ Only the Connecticut and New York constitutions mentioned public prosecutors, both states providing for judicial appointment. ${ }^{35}$ Later state constitutions further distinguished prosecuting attorneys from officials with quintessentially executive duties ${ }^{36}$ sometimes relegating prosecuting attorneys to a subsection of articles establishing the structure and officers of state courts. ${ }^{37}$ Finally, as Jacksonian democracy swept the country in the 1830's, prosecutors followed judges into elective status. ${ }^{38}$ Only after these various reforms to ensure the independence of prosecutors did the office at last appear in the executive article of some new state constitutions passed immediately prior to the Civil War. ${ }^{39}$

In sum, the colonial prosecutorial heritage supports the Morrison majority's conclusion that prosecution is not a core executive function: Colonial and state constitutions did not assign the prosecutorial function to the

30. See J. Goebel \& T. Naughton, supta note 16, at 332-34.

31. Mississippi in 1817 and Louisiana in $\mathbf{1 8 1 2}$ separated the prosecuting attorney from the attorney general, who served as advisor to the executive. See Miss. ConsT. of 1817, art. V, $\S 14 ;$ LA. Const. of 1812 , art. IV, $\S 3$.

32. See J. JАСОВY, supra note 18 , at 20.

33. The constitutions of Georgia, Maryland, Massachusetts, New Jersey, and Virginia include the office of attorney general in the judicial article. See J. JACOBY, supra note 18, at 22.

34. See supra note 22 and accompanying text.

35. See supra note 13; N.Y. Consr. of 1777 , art. XXVII.

The location of the power to appoint prosecutors varied widely in state statutes. The power resided in the Governor in Pennsyivania, the attorney general in North Carolina, and the local court in Virginia. See J. JAcoBY, supra note 18, at 21. However, no state in 1787 gave the executive unlimited removal powers, thus restricting the amount of influence the appointment power carried. See Myers v. United States, 272 U.S. 52, 247-48 (1926) (Brandeis, J., dissenting).

36. States distinguished the prosecutor from the attorney general, who was legal advisor to the executive, and the sheriff, who embodied the executive function of law enforcement. See J. JACOBY, supra note 18 , at $22-25$.

37. See, e.g., Miss. Const of 1832, art. IV, § 25.

38. See J. JACOBY, supra note 18 , at 25.

39. See id. 
executive branch; executive officials did not always prosecute; and prosecutors were local officials not subject to centralized control.

However, one caveat limits the usefulness of this heritage as an indicator of the Framers' intent on the "core executive" nature of prosecution: The separation of powers doctrine did not dominate colonial government organization. ${ }^{40}$ At the level of practice, colonial and state governments did not functionally differentiate among the branches. ${ }^{41}$ Even at the level of theory, contemporaneous political thinkers failed to distinguish fully the executive from the judicial function. ${ }^{42}$ Nonetheless, given the increased importance the separation of powers doctrine was about to assume, one would expect to find some discussion if the Framers had decided to abandon their heritage by establishing an active public prosecutor subject to centralized, presidential control. Section II will examine the Framers' debates and writings for such an express departure.

\section{The Framing of the Constitution}

The Framers could have established prosecution as a core executive function in one of two ways: by assigning the function to the President or by prohibiting other constitutional actors from influencing this function. Part A will examine the three Article II provisions invoked to support presidential prosecution: the "executive power" clause, ${ }^{\mathbf{4 3}}$ the "take care" clause, ${ }^{44}$ and the pardon power. ${ }^{45}$ Part B will examine constitutional preclusions to the nonpresidential prosecution that occurs under the Ethics in Government Act.

\section{A. The "Executive Power" Clause}

The Supreme Court has been equivocal about the scope of the executive power clause. Some Justices have urged that the clause vests additional powers in the President, while others have argued that it is wholly redun-

40. See A. Kelly, W. Harbison \& H. Belz, The American Constitution: Its Origins AND DEVELOPMENT 30-31 (1983).

41. The Governor, Council, and elected deputies, who together formed the legislature, shared responsibility for "government tasks"-policy questions in today's parlance. Id. at 31-32. Even after independence, merged functions remained. In New Hampshire, the legislature awarded new trials after judgment four times between 1791 and 1817. F. Aumann, The Changing American Legal. System: Some Selected Phases 164-66 (1940). At the time of the Framing, southern state legislatures continued as the dominant branch of government, exercising both administrative and executive functions. See F. Green, Constitutional Development in the South Atrantic States, 1776-1860, at 83 (1930).

42. See M. Vile, Constitutionalism and the Separation of Powers 28-29 (1967) (idea of executive power distinct from law enforcement through courts not fully developed until end of eighteenth century).

43. "The executive Power shall be vested in the President of the United States of America." U.S. Consr. art. II, $\S 1$, cl. 1.

44. "[The President] shall take Care that the Laws be faithfully executed ...." U.S. ConsT. art. II, $\S 3$.

45. "The President ... shall have Power to grant Reprieves and Pardons for Offenses against the United States, except in Cases of Impeachment." U.S. CoNST. art. II, $\S 2$, cl. 1. 
dant. ${ }^{46}$ The lack of a consistent definition of executive power in the Framers' debates and writings helps to explain this ambivalence.

A number of comments early in the debates indicate that the Framers viewed executive power broadly. On May 29, 1787, Edmund Randolph proposed that "besides a general authority to execute the National laws, [the executive] ought to enjoy the Executive rights vested in Congress by the Confederation." ${ }^{37}$ Then on June 1, the delegates defeated as unnecessary a motion to extend the executive power to include "such other powers, not Legislative or Judicial in their nature, as may from time to time be delegated by the national Legislature." 48 Madison was of the opinion that the "power to carry into effect the national laws" also included the appointment power, although he supported the enumeration of this power to avoid confusion. ${ }^{49}$

This broad notion of executive power ended with the Committee of Detail's fourth draft, which vested in the President the specifically enumerated powers to control the militia, recommend and veto legislation, commission officers, receive ambassadors, and convene Congress. ${ }^{.0}$ The Federalists and Antifederalists in the remainder of the debates and in their letters confined themselves to a discussion of these enumerated powers. ${ }^{51}$ Strategically, this would seem wise for the Federalists, who depicted a limited executive to allay fears of an elective monarch; it makes little sense for the Antifederalists, who went to great lengths to grease the slippery slope back to the days of George III. Given the Antifederalists' concern over the enumerated powers of the executive, they certainly could not have been comfortable with an unbounded "executive power" clause: The Antifederalists must have believed either that the introductory clause conferred no additional powers, or that "executive power" had an acceptable,

46. Compare Myers v. United States, 272 U.S. 52, 117-18 (1926) ("executive power" clause vests additional power in President) with Youngstown Sheet \& Tube Co. v. Sawyer, 343 U.S. 579, 587 (1952) (clause confers only powers expressly enumerated in Article Two).

47. 1 M. Farrand, The Records of the Federal Convention of 1787, at 21 (1937). The executive rights under the Confederation did not include any prosecutorial powers, a fact which is not surprising since there was no national judiciary or federal criminal laws. See Guggenheimer, The Development of the Executive Departments, 1775-1789, in Essays IN THE ConstrTutional History of the United States in the Formative Period, 1775-1789, at 116 (J. Jameson ed. 1889); Amar, Of Sovereignty and Federalism, 96 YALE L.J. 1425, 1444-60 (1987).

48. 1 M. FARRAND, supra note 47 , at 67.

49. See id. at 57. However, this conception of the appointment power as exclusively executive did not prevail. See Blumoff, Separation of Powers and the Origins of the Appointment Clause, 37 SyraCUSE L. REv. 1037, 1061-70 (1987).

50. This draft included the military provisions in parentheses, 7 M. FARRAND, supra note 47, at 145-46, perhaps indicating that the Committee viewed the President's military powers to be synonymous with the power to carry into execution the national laws. Some of the Antifederalists' writings evince this conception of law execution through the use of military force. See, e.g., C. KENYON, THE ANTifederalists 229, 248 (1966) (Richard Lee on military execution of law; Patrick Henry on President at head of standing army as "executor").

51. See, e.g., The Federalist No. 67, 69, 71-77 (C. Rossiter ed. 1961) (Hamilton's considerãtion of the presidential office); C. KENYON, supra note 54, at 87, 194, 299 (discussing veto, pardon and treaty powers). 
definitive meaning. Yet nowhere in the debates or public writings do the Framers offer such a definition. ${ }^{62}$ The lack of such a definition and of any discussion of prosecution in connection with the "executive power" makes it unlikely that the Framers intended the introductory clause to be the basis for exclusively presidential prosecution.

\section{B. The Take Care Clause}

The Supreme Court has also been equivocal concerning the take care clause as a basis for executive power. ${ }^{53}$ Certainly the tone of this clause provides a shaky foundation for a President to claim unfettered prosecutorial discretion; the provision reads more like the imposition of an obligation than the granting of a power. ${ }^{54}$

The lineage of the take care clause supports the conception of this provision as a duty, not a power. The earliest roots of the clause appear in the English courts' denial of James II's efforts to suspend or dispense with Acts of Parliament. After the Glorious Revolution of 1689, Parliament enacted the English Bill of Rights, which prohibited the suspension or execution of laws without Parliamentary authority. ${ }^{\mathrm{ss}}$ Several state constitutions included similar provisions. ${ }^{56}$

Finally, the placement of this clause in section three also argues against this provision as a basis for a core executive function. Section three evolved as a residuary clause for powers so limited and ceremonial as to appear more like duties. The take care clause did not appear until the Committee of Detail's seventh draft, ${ }^{57}$ in which the Committee classified it as a "Duty" together with clauses concerning the state of the union address and the recommending of legislation. The Committee of Style then regrouped the take care clause ${ }^{58}$ with the limited convening and adjourning powers and the clauses concerning the state of the union address, the

52. See Winterton, The Concept of Executive Power in Domestic Affairs, 7 Hastings Const. L.Q. 1, 24-29 \& n.160 (1979) (rejecting broad view of executive power clause); P. SHANE \& H. Bruff, The Law of Presidential Power 8-12 (1988) (Constitutional Convention delegates held wide variety of views on executive power and, therefore, "established a Presidency with powers that resist definition").

53. See Myers v. United States, 272 U.S. 52, 177 (1926) (Holmes, J., dissenting), quoted with approval in Youngstown Sheet and Tube Co. v. Sawyer, 343 U.S. 579, 610 (1952) (Frankfurter, J., concurring).

54. The active verb "take care" is far from forceful; the phrase concerning the execution of the laws is in the passive voice; and "executed" is further qualified by "faithfully," as it is in the President's required oath of office, U.S. CoNST. art. II, $\S 1$, cl. 8.

55. 1 W. \& M., Sess. 2, ch. 2 (1688); see Reinstein, An Early View of Executive Powers and Privilege: The Trial of Smith and Ogden, 2 Hastings Const. L.Q. 309, 320-21 n.50 (1975).

56. New York, Pennsylvania, and Vermont provided the duty in the form most similar to the Federal Constitution by including the "take care" clause with many of the less significant powers which appear in Article Two, section three. N.Y. CoNST. of 1777 art. XIX; PA. CoNST. of 1776 art. XX; VT. Const. of 1777 art. XVIII.

57. "Duty . . . to attend to the Execution of the Laws of the U.S. . . to expedite all such Measures as may be resolved on by the Legislature." 2 M. FARRAND, supra note 47, at 158.

58. The President "shall take care that the laws of the United States be duly and faithfully executed ...." Id. at 574-75. 
recommending of legislation, the commissioning of officers, and the receipt of ambassadors. Conspicuously absent from this grouping was the word "power." Except for the convening and adjourning clauses, which employed "may," the verb used was "shall," which implied that these were the duties of the President. ${ }^{59}$ The debates and the Framers' letters further support the ceremonial nature of section three. ${ }^{60}$ In brief, the increasing segregation of these duties and less important powers from quintessentially executive powers argues against using the take care clause as the basis for a core executive function. ${ }^{\text {11 }}$

\section{The Pardon Power}

The most obvious basis in Article Two for the contention that prosecution is a core executive function is the presidential pardon power. Unlike the "executive power" clause, there can be no question that this clause confers an additional power; unlike the "take care" clause, this provision undoubtedly concerns a power, not a duty, and criminal, not civil, prosecution. Given the Framers' belief that this power could be exercised before conviction, ${ }^{62}$ a clever President could use this power as both an axe and a scalpel, threatening to pardon individuals who were not being prosecuted according to the Chief Executive's wishes. ${ }^{68}$

Both the colonial heritage and the Framers' discussions of the pardon power show that the Founding Fathers did not intend that the President use his pardon power to achieve unfettered prosecutorial discretion. First, some colonies, in line with their British heritage, vested the pardon power and prosecutorial discretion in separate entitites. ${ }^{.4}$ Second, the Framers,

59. Id. at 404. The Framers provided for a similar distinction between permissive and mandatory clauses in Article III. See Amar, A Neo-Federalist View of Article III: Separating the Two Tiers of Federal Jurisdiction, 65 B.U.L. REv. 205, 212 (1985).

60. This section was not the subject of any heated discussions at the Convention; the clauses were entirely the creation of the two drafting committees. Hamilton in Federalist No. 77 contends that only the power to convene Congress and receive ambassadors raised objections from the Antifederalists. The Federalist No. 77, at 463 (A. Hamilton) (C. Rossiter ed. 1961). Hamilton saw receiving ambassadors as "more a matter of dignity than of authority," inserted to avoid convening the legislature for the arrival of every foreign minister. THE FEDERALISr No. 69, at 420 (A. Hamilton) (C. Rossiter ed. 1961). While Hamilton did have reason to mitigate the importance of these powers, he probably would have considered them more intensely had they been controversial. An examination of the Antifederalist papers shows that they were not. For the only expression of alarm concerning the receipt of ambassadors in Kenyon's The Antifederalists, see C. KENYON, supra note 50, at 306.

61. See H. Koh, The National Security Constitution: Sharing Power After the IRAN-CONTRA AFFAIR 76 (1990) (take care clause imposed upon the president "a duty rather than a license"); L. Henkin, Foreign Affairs and the Constrmution 54 (1972) ("The principle purport of the clause, no doubt, was that the President would be a loyal agent of Congress to enforce its laws.").

62. See, e.g., The Federalist No. 74, at 447-49 (A. Hamilton) (C. Rossiter ed. 1961).

63. In other words, the President could use the pardon power to influence prosecution much as he uses the veto power to influence law making.

64. In Britain, private prosecution existed alongside royal pardons. Compare supra notes 11-12 and accompanying text with W. Humbert, The Pardoning Power of the President 9-11 (1941). In the Georgia Constitution of 1786 the Governor had the pardon power and the judicial article included the public prosecutor. GA. CoNST. of 1786, arts. II and III. 
like their colonial and British ancestors, emphasized the exceptional nature of the act. ${ }^{6 \mathrm{~B}}$ Both the arguments for and against the pardon power employed great state crimes as examples: Federalists predicted the pardoning of repentant rebels to avoid an impending revolution, while Antifederalists feared the pardoning of accomplices in a treasonable conspiracy involving the President. ${ }^{88}$ These examples, unlike the routine exercise of prosecutorial discretion, carried with them great publicity and attendant political danger.

Third, the distinction between the pardon power and prosecutorial discretion becomes apparent if the practice of prosecution is divided into its three subsidiary powers, each distinguishable by the degree of involvement of public prosecutors. As seen in Section I, the power to initiate belonged to private parties in the vast majority of criminal cases. Private parties also supervised prosecution, since in the bulk of criminal trials the individual parties settled, and in the vast majority of the remainder, plaintiffs conducted their own cases in informal hearings. Public prosecutors' most accepted role in common criminal cases was to end prosecutions, a power historically grounded in the use of the nolle prosequi by the British attorney general. ${ }^{67}$

The pardon power resembles the nolle prosequi authority, the "prosecutorial" power most closely associated with public prosecutors in 1789. This power to end individual prosecutions for the larger public good is most tenably what the Framers thought they were vesting in the President by granting him the power to pardon. It is simply illogical to claim that the Framers implicitly intended to vest the President with the power to initiate prosecutions by expressly giving him the power to end prosecutions. Nor is it likely that they equated the power to stop a prosecution with the power to conduct a prosecution, since in most contemporary criminal suits the individual parties personally directed cases. ${ }^{68} \mathrm{Fi}$ nally, practical considerations reinforced this division of the prosecutorial powers. Presented with the same distance and communication barriers that fostered independent, locally based colonial prosecutors, the Framers could not have envisioned a President using the pardon power to do much in advance of ending a prosecution long after it had begun.

In conclusion, little in the Constitution or public writings suggests that the Framers intended to limit prosecutorial discretion to the exclusive control of the President. The "executive power" clause, even in its more gen-

\footnotetext{
65. See W. Humbert, supra note 64 , at 9-14.

66. See 2 J. Elliot, The Debates in the Several State Conventions on the Adoption of the Federal Constitumion 110-14 (1887); C. KenYon, supra note 50, at 304.

67. See supra note 26 and accompanying text.

68. The Ethics in Government Act preserves the President's ability to stop prosecution: The Attorney General has the unreviewable discretion both not to appoint an independent counsel and to remove an independent counsel for good cause; the President retains his pardon power. See supra note
} 2. 
eral definitions, never provoked discussions of prosecution. The take care clause in its tone, placement, and lineage was an obligating, not an empowering, clause. The pardon provision, while undoubtedly granting an additional power, brought with it a colonial history, distinct from that of prosecutorial discretion, which went unchallenged by the Framers.

\section{Non-Presidential Prosecution .}

This section explores the argument that the Framers implicitly vested the President with exclusive prosecutorial discretion by prohibiting prosecution by other constitutional actors. In the context of the Ethics in Government Act, these prohibitions would preclude congressional initiation, judicial appointment and exercise of ministerial tasks, and independent prosecution. ${ }^{68}$ No such prohibitions appear in the text or debates.

Unlike the introductory clauses of Articles Two and Three, Article One, section one limits the powers of Congress to those specifically enumerated in the Article. ${ }^{70}$ Thus, at first glance, the failure to enumerate congressional initiation of prosecution would appear to preclude this power. However, the exercise of investigatory powers by Parliament and by colonial and state legislatures probably indicates that the Framers viewed this as an inherent attribute of legislative bodies. ${ }^{71}$ This inherent investigatory power would thus support a passive role for Congress in petitioning the Attorney General to appoint an independent counsel. The "necessary and proper" clause ${ }^{72}$ would appear to support the more intrusive role evident in the Ethics in Government Act's provision that the Attorney General has only 90 days to make his decision. ${ }^{73}$

In contrast to their consideration of the more general separation of powers question, the Morrison majority did reveal the Framers' support for judicial appointment of independent counsel. In short, the majority concluded that the debates contained nothing to suggest that the Framers intended to prevent Congress from providing for interbranch appointments. ${ }^{74}$ The majority also used the appointments clause as a foundation for the Special Division's limited discretion to set the independent coun-

69. See supra note 2 .

70. For an early discussion in the Convention on the need for enumeration of congressional power, see $1 \mathrm{M}$. FARRAND, supra note 47 , at 53.

71. See Landis, Constitutional Limitations on the Congressional Power of Investigation, 40 HaRv. L. Rev. 153, 159-70 (1926); Potts, Power of Legislative Bodies to Punish for Contempt, 74 U. PA. L. REv. 691, 780 (1926). In other words, the Framers believed that all of the legislative powers enumerated in Article I subsumed the power to gather information, along with the other subsidary "powers" of law-making, such as the power to make motions, debate, and vote.

72. "[The Congress shall have Power] To make all Laws which shall be necessary and proper for carrying into Execution the foregoing Powers, and all other Powers vested by this Constitution...." U.S. Const. art. I, \& 8, cl. 18 .

73. See generally Krent, Executive Control over Criminal Law Enforcement: Some Lessons from History, 38 AM. U.L. Rev. 275, 282-85 (1989) (constitutional bases for congressional role in shaping law enforcement); infra note 83 .

74. See Morrison v. Olson, 108 S. Ct. 2597, 2611 (1988). 
sel's jurisdiction. Nothing in the debates prohibits this boot-strapping. Nor is there any discussion of how Article III might limit the appointment power. ${ }^{78}$

The Morrison majority interpreted the remainder of the Special Division's powers as ministerial tasks involving the exercise of little discretion. ${ }^{78}$ Article Three does not prohibit the exercise of such powers. The introductory clause of Article Three, ${ }^{77}$ unlike that of Article One, does not limit the judicial power to the powers enumerated in Article Three. Any prohibition of prosecution as a judicial function must therefore arise from a definition of "judicial power" openly accepted by the Framers. However, as with "executive power," there is no such definitive meaning; the Framers blurred executive and judicial powers as did their colonial ancestors $^{78}$ While the case and controversy clause ${ }^{79}$ appears to limit judicial power to adversarial proceedings, judicial involvement in prosecution was not among those extra-judicial tasks rejected by the Framers. ${ }^{80}$

Discerning the Framers' intent on independent executive prosecution proves even more complicated than divining their intent on congressional initiation or judicial appointment and administration. In line with the analysis thus far, the examination of the Constitution and related writings should focus on provisions prohibiting independent executive officials from prosecuting. While no provision resembling such a preclusion exists, ${ }^{81}$ there is a more fundamental challenge to independent executive prosecution. This challenge goes to the existence of any independent executive departments, regardless of their function. The introductory "executive power" clause presents the strongest argument against the existence of independent executive officials. This clause spawned debates on the need for a unitary executive. Taken out of context, these remarks seem to extol

75. See 1 M. FARRAND, supra note 47, at 232-33; 2 M. FARRAND, supra note 47 , at 42-44, 80-83, 183-84, 498-99, 599, 627-28.

76. $108 \mathrm{~S}$. Ct. at 2613-15. These powers include the receipt of reports and the termination of the office when the counsel's task is complete.

77. "The judicial Power of the United States, shall be vested in one Supreme Court, and in such inferior courts ...." U.S. ConST. art. III, \&1.

78. Compare supra note 42 and accompanying text with C. KenYoN, supra note 50, at 326 (quoting Robert Yates: "the officers of these courts will execute their judgments") and $3 \mathrm{~A}$. HAMILton, The Papers of Alexander Hamilton 543-45 (H. Syrett ed. 1961) (trial by jury as "antient and highly esteemed mode of prosecution").

79. U.S. ConST. art. III, \& 2.

80. See 1 M. FARRAND, supra note 47, at 21, 97-104, 108-110, 138-40; 2 M. FARRAND, supra note 47 , at 73-80, 298, 328-29, 342-44, 430, 627; C. WARREN, The Making of the ConstrtuTION 643-50 (1937).

The Fifth Amendment's role for the grand jury in the initiation of prosecution may provide a positive basis for judicial prosecution. Given the courts' special relationship with grand juries, the Framers may have been amenable to judicial ministerial tasks, at least in the initiation stage. See generally Note, The Proposed Court-Appointed Special Prosecutor: In Quest of a Constitutional Justification, 87 YALE L.J. 1692 (1978).

81. As with the President, Congress, and the judiciary, no explicit discussion of the prosecutorial function occurred in connection with executive departments, not even in the Framers' consideration of a Home Secretary. See 2 M. FarRand, supra note 47, at 329, 335-36, 367. 
the advantages of presidential control over executive officials. Taken in context, these remarks bemoan the disadvantages of executive council control over the President. ${ }^{82}$ The other tangential clauses on executive departments show that the Framers never decided against the perpetuation of the colonial heritage of independent, locally-based officials. ${ }^{83}$

In sum, an analysis of the Framing does not contradict the Morrison majority's conclusion on the executive nature of prosecution and its resultant decision to uphold the Ethics in Government Act. First, the Framers did not constitutionally assign the prosecutorial function, either by vesting it in the President or by precluding its exercise by all other constitutional actors. Second, while an investigation of early federal practice will provide a clearer answer as to which officials typically prosecuted, the Framers certainly expressed no preference for one constitutional actor over another. Finally, the Framers did not require that the President control prosecution.

\section{Early Federal Practice}

An examination of the history of the Federal Government during the first decade following the ratification of the Constitution provides additional insight into the Framers' intent. During this period, the need to fill in the practical details of the recently established government urgently confronted the Framers. The structure of the Federal prosecutorial system was one such detail. As argued in the previous section, if the Framers had any definitive thoughts about this system, they seemed unwilling to share them with posterity. Although one could argue that the uncertain meaning of these terms left the decision as to where to vest the prosecutorial function to future law makers, an immediate, unequivocal decision by the Framers to vest exclusive prosecutorial discretion in the President might show that the relevant intent, today obscured, was in 1787 too obvious to debate.

Two aspects of Federal prosecutorial practice help to reveal the Framers' intent on prosecution as a core executive function. Part A considers the extent to which Federal practice followed the colonial heritage of pri-

82. See, e.g., 1 M. FARRAND, supra note 47, at 64, 68.

83. The appointments clause, U.S. ConsT. art. II, $\S 2$, cl. 2 , allows Congress to delegate to department heads the power, to be exercised free from presidential interference, to appoint inferior officials. See Note, In Defense of Administrative Agency Autonomy, 96 YALE L.J. 787, 799 (1987). The "necessary and proper" clause, U.S. Consr. art. I, \& 8, cl. 18, vests Congress with the power to assist executive departments in fulfilling their independent constitutional duties. See id. The "opinion in writing" clause, U.S. CoNST. art. II, $\S 2$, cl. 1, appears to envision independent department heads, since this clause would be superfluous if the President could fire the officials at will. See Note, supra, at 800 . However, Hamilton contended that the clause was "a mere redundancy," a power already contained within the President's general executive powers. THE FEDERALIST No. 74, at 447 (A. Hamilton) (C. Rossiter ed. 1961); see Bestor, Separation of Powers in the Domain of Foreign Affairs: The Intent of the Constitution Historically Examined, 5 SETON HALL L. REv. 527, 643-52 (1974). 
vate prosecution and independent, locally-based prosecution. Part B examines the extent of congressional and judicial influence on prosecution.

\section{A. Independent Versus Presidential Prosecution}

In contrast to colonial criminal justice systems, a private right of prosecution did not develop in the Federal system. Two factors explain this absence. First, the Supreme Court refused to recognize federal common law crimes which might have given rise to private prosecution. ${ }^{84}$ Second, federal criminal statutes during this period dealt with crimes against the Federal Government qua Federal Government, and thus, public officials prosecuted these public crimes. ${ }^{85}$

Yet despite the absence of a private prosecution system, private participation continued in two important respects. First, private citizens in the early Federal period could directly initiate prosecutions. Citizens obtained bench warrants from magistrates for the arrest of defendants and presented evidence of crimes directly to grand juries. ${ }^{86}$ In a 1794 opinion, Attorney General Bradford expressed his belief that citizens could force a district attorney to act on a grand jury presentment, even after the district attorney had decided not to prosecute. ${ }^{87}$ Second, Congress on a number of occasions chose to bolster enforcement of Federal criminal statutes with private qui tam actions. ${ }^{\mathbf{8}}$ By conducting a qui tam action, a private citizen could preclude the executive branch from initiating a criminal prosecution for the same conduct. ${ }^{\text {so }}$

Private attorneys and state officials also participated in Federal prosecution. Federal departments and local officers routinely resorted to hiring private attorneys as "special counsel" to prosecute government cases. ${ }^{80}$ The vesting of jurisdiction in state courts to hear at least some criminal prosecutions resulted in state officials initiating and conducting Federal criminal prosecutions. ${ }^{91}$

Despite some participation in prosecution by private individuals and

84. United States v. Hudson \& Goodwin, 11 U.S. (7 Cranch) 32 (1812). Prosecution for federal common law crimes did, however, occur in the 1790's. See J. Goebel, History of THE Supreme Court of the United States: Antecedents and Beginnings to 1801, at 623-25 (1971). Thus, private Federal prosecutions may also have occurred.

85. See, e.g., Krent, supra note 73 , at 296 n.104.

86. See id. at 292 .

87. See id. at 293-94.

88. The phrase "qui tam" stands for "qui tam pro domino rege quam pro se imposo sequitur," translated as "who brings the action as well for the king as for himself." See Bass Anglers Sportsman's Soc'y of America v. U.S. Plywood-Champion Papers, Inc., 324 F. Supp. 302, 305 (S.D. Tex. 1971).

89. Courts treated qui tam proceedings as criminal for purposes of statutes of limitation, evidentiary rulings, and the relevant standard of proof. Individuals thus set Federal criminal law policy both by litigating specific cases and by shaping precedents. See Krent, supra note 73, at 300; Caminker, The Constitutionality of Qui Tam Litigation, 99 YALE L.J. 341, 342-46 (1989).

90. H. Cummings \& C. McFarland, Federal Justice: Chapters in the History of JusTICE AND THE Federal EXeCUTIVE 225, 229 (1937).

91. See Krent, supra note 73, at 305-06. 
state officials, officials in the Federal executive branch conducted the bulk of Federal prosecution. For the purposes of the Morrison analysis, however, the key question is the extent of presidential control over these executive officials. Dividing presidential control into appointment, direction, and removal helps to focus the search for presidential prosecution in early Federal practice. ${ }^{22}$ Constitutional actors in search of the Framers' intent on questions of removal can look to the Supreme Court opinions in Myers v. United States ${ }^{93}$ and Humphrey's Executor v. United States. Humphrey's Executor distinguished Myers by concluding that the Framers did not consider the President's removal powers to be illimitable with respect to officers who were not purely executive."4 Thus, the removal of independent counsel depends on whether prosecution is a core executive function. ${ }^{85}$

An examination of the drafting of the Federal Judiciary Act sheds additional light on the appointment aspect of control. Although the final version of the Judiciary Act of 1789 vested the appointment of the Attorney General in the President, an earlier draft vesting this power in the Supreme Court indicates that its authors did not feel that presidential appointment was constitutionally compelled..$^{96} \mathrm{~A}$ letter from Robert Livingston, which may have prompted changes subsequently made by Oliver Ellsworth, reinforces this conclusion. First, Livingston suggested that appointment by the executive would be "better"9z (not constitutionally compelled). Second, Livingston's recommendation concerned appointment of the Attorney General, not the United States attorneys. Like his English and colonial predecessors, the Attorney General acted primarily as a legal advisor, with only limited direct involvement in prosecution until after $1870 .^{98}$ The original draft of the Act vested appointment of United States attorneys in Federal district courts, again indicating the lack of constitutional compulsion to vest appointment in the President. In fact, the final draft of the Act did not specify who should appoint United States attor-

92. In terms of the Ethics in Government Act, these three subsidiary powers correspond to the three stages of prosecution: initiation, conduct and termination.

93. 272 U.S. $52,109-60$ (1926).

94. 295 U.S. 602,631 (1935).

95. Morrison v. Olson, 108 S. Ct. 2597, at 2616-20 (1988).

96. See Warren, New Light on the History of the Federal Judiciary Act of 1789, 37 Harv. L. REv. 49, 108-09 (1924).

97. See Letter from Robert Livingston to Oliver Ellsworth (June 26, 1789) (on file at Huntington Library, San Marino, Cal.). Moreover, it seems doubtful that Livingston was a proponent of presidential prosecutorial discretion, since he proposed an amendment which would have limited the President's pardon power. See 2 J. ElLIOT, supra note 66, at 408.

98. The Attorney General initially advised not only the President, but also heads of departments and Congress. See L. Huston, The Department of Jusrice 8 (1967). He argued cases only before the Supreme Court, which did not entertain direct review of criminal actions in capital cases until 1889. Before that time, the Supreme Court heard criminal matters only through habeas corpus or when there was a division of opinion within the two-judge circuit court. See Krent, supra note 73, at 287 n.52. 
neys, although in practice the President made these appointments. ${ }^{99}$ Thus, the Framers did not view presidential appointment of prosecutors as the obvious choice.

The Framers also failed to establish immediately presidential direction of prosecution. The Attorney General did not have supervisory charge of the United States attorneys, the primary federal prosecutors at this time, despite Attorney General Randolph's attempt to gain such control. ${ }^{100}$ Nominally, the United States attorneys were under the supervision of the Secretary of State, who had been somewhat haphazardly assigned the additional duties of a Home Secretary. However, contacts between the district attorneys and the Department of State were "largely fortuitous." 101 In general, the district attorneys conducted prosecutions for federal officials on a fee basis. The largest group of cases requiring the services of the U.S. attorneys arose from customs and internal revenue offenses brought to their attention by local revenue officers. These actions arose from congressional authorization of the Comptroller to direct prosecutions for all debts due the United States. ${ }^{102}$ The district attorneys also assisted the Postmaster General in prosecuting mail offenses and in suits against delinquent postmasters and their sureties. ${ }^{103}$ Both the Comptroller and the Postmaster General were independent executive officials. ${ }^{104}$ Their congressional insulation from presidential control in turn insulated the United States attorneys. Yet, in practice, the district attorneys usually acted on their own discretion even in these cases. ${ }^{105}$

Finally, no evidence exists to show that the President exercised his pardon power to gain control over the prosecutorial function. The President confined his use of the pardon power to ending prosecutions of great state crimes after the United States attorneys had begun their independent conduct of the prosecution. Even in the volatile Whiskey Rebellion cases,

99. Judiciary Act of 1789 , ch. $20, \S 35,1$ Stat. 92 (1861); cf. Warren, supra note 96 , at 109 n.137.

100. Letter of Edmund Randolph to President Washington, Dec. 26, 1791, reprinted in 1 AMERican State Papers, Class X, Miscellaneous, No. 25, at 46 (1834).

101. The district attorneys received no standard instructions and filed no regular reports. More direct involvement seemed limited to cases with foreign policy implications. See L. WHITE, THE FEDERALIST: A StUdy IN ADMinistrative History 408 (1948). Yet even this category was not without exception. See Krent, supra note 73, at 295 n.55; United States v. Smith, 27 F. Cas. 1192 (C.C.D.N.Y. 1806) (No. 16,342), discussed in H. KoH, supra note 61, at 82-83 (prosecutor appears to act independent of presidential direction).

102. Act of May 15, 1820, ch. 107, § 1, 3 Stat. 592.

103. See L. White, The JefFersonians 340 (1961).

104. See Tiefer, The Constitutionality of Independent Officers as Checks on Abuses of Executive Power, 63 B.U.L. Rev. 59, 71-75 (1983); Note, supra note 83, at 806.

105. In the bulk of cases, the district attorneys acted independently with discretionary powers drawn chiefly from English precedents. See L. WHIrE, supra note 103, at 167-69, 488. In 1823 Attorney General Wirt denied the district attorneys' right to seek professional assistance from either the Treasury or the Attorney General, since prosecutorial decisions had been "referred exclusively to [their] own learning." 2 Op. Att'y Gen. 611 (1823). 
President Washington waited until after conviction to exercise his pardon power. ${ }^{108}$

In sum, early Federal prosecutorial practice retained some important links to its colonial heritage. While the prevalence of private prosecution could not persist in a system lacking a common law of crimes, private individuals and state officials did play a more limited role in the Federal system. More importantly, Federal prosecution did perpetuate the independence of public prosecutors.

\section{B. Congressional and Judicial Influence on Prosecution}

Early congressional "prosecution" supports the limited involvement of Congress in the Ethics in Government Act. Congressional investigative power, unenumerated in the Constitution, quickly surfaced as an inherent congressional authority, thus providing a basis for legislative initiation of prosecution. ${ }^{107}$ Congress influenced the conduct of Federal prosecution through legislation: Congress vested the prosecutorial function in a number of independent executive officials and further dispersed the function by providing for private party and state participation. ${ }^{108}$ Congressional control of the entire prosecutorial function occured pursuant to congressional contempt power. ${ }^{109}$ These examples of congressional influence provide sufficient historical support for the less intrusive imposition of a time limit on the Attorney General's decision to appoint an independent counsel.

Early Federal prosecutorial practice also serves as a foundation for judicial appointment in the Ethics in Government Act. As seen in the drafting of the Federal Judiciary Act, the Framers did not believe that the Constitution precluded judicial appointment of prosecutors. ${ }^{110}$ District court judges did in fact make temporary appointments of United States attorneys. ${ }^{111}$ Judicial appointment of prosecutors in contempt proceedings provides yet another historical basis for the Ethics in Government Act. ${ }^{\mathbf{1 1 2}}$

106. See R. Morris, Alexander Hamilton and the Founding of the Nation 485 (1957).

107. In 1792 the House conducted a committee inquiry into the failure of General St. Clair's expedition against the Indians of the Ohio country. See Chalou, St. Clair's Defeat, in Congress INVESTIGATES: 1792-1974, at 1-18 (A. Schlesinger \& R. Burns eds. 1975). During the nineteenth century, Congress employed commissions to collect evidence and make reports on private claims, for the use of the courts, executive officers, and Congress itself. See Tiefer, supra note 104, at 76-77.

108. See supra notes 90-91, 102-04 and accompanying text. Congress could also influence the conduct of prosecution through its spending powers. See generally Stith, Congress' Power of the Purse, 97 Yale L.J. 1343, 1386-98 (1988).

109. In 1796, the House of Representatives tried, convicted, and imprisoned a private citizen on charges of congressional bribery. See Moreland, Congressional Investigations and Private Persons, 40 S. CAL. L. Rev. 189, 190-91 (1967). However, the Framers probably intended to limit this power to cases of institutional "self-defense"-that is, cases involving the obstruction of the duties of Congress qua legislature-not to provide the basis for a general prosecutorial function. See generally Potts, supra note 71 , at 780 .

110. See supra notes $96-99$ and accompanying text.

111. See generally United States v. Solomon, 216 F. Supp. 835 (S.D.N.Y. 1963).

112. See Young v. United States ex rel. Vuitton et Fils S.A., 481 U.S. 787, 795-96 n.7 (1987). As 
Finally, the Morrison majority also supported court appointment by noting instances of judicial appointment of defense attorneys and court officials. $^{118}$

While early Federal practice failed to clarify the limits of "judicial power,"114 two famous examples of early Federal prosecution demonstrate active judicial supervision of the prosecutorial function. First, Federal courts' aggressive use of grand juries in Alien and Sedition Act prosecutions provides support for judicial "prosecution" at least through the initiation stage. ${ }^{116}$ Second, Hamilton's correspondence with President Washington reveals that judges prosecuted those convicted for the Whiskey Rebellion of $1794{ }^{116}$ This active role for judges in certain early Federal prosecutions provides sufficient support for the ministerial tasks undertaken by the Special Division in the limited circumstances of the Ethics in Government Act. The absence of early case law excluding prosecution from the definition of judicial power reinforces this conclusion. ${ }^{117}$

In brief, early Federal prosecutorial practice parallels the Framers' intent which emerges from the Constitution and related records: The Founding Fathers did not conceive of prosecution as the exclusive function of the President, nor even of the executive branch. Prosecution was occurring under the influence of advisors to the President, locally-based district attorneys, independent executive officials, private citizens, state officials, judges, and Congress. The varying influence of the major constitutional actors coincided with the historical distinction between initiation, direction, and termination. Congress confined its involvement to legislating and the "initiating" acts of investigation. The judiciary confined its influence to appointment, grand jury "initiation," and limited supervision, although the continued blurring of judicial and executive powers could have resulted in a greater judicial role. Independent, locally based executive officials conducted the bulk of public prosecution. The President limited his control to the "terminating" acts of pardoning and removal for good cause. Grounded in this historical distinction, early Federal practice in turn sup-

with congressional contempt power, the Framers probably intended to limit this power to cases of institutional self-defense, not to provide a basis for general, prosecutorial power. See supra note 109.

113. Morrison v. Olson, 108 S. Ct. 2597, 2611 n.14, 2612 n.16 (1988).

114. Commentators failed either to relate "judicial power" to the judiciary's appointment power or to distinguish it from "executive power." The debates on the establishment of lower Federal courts exhibit this confusion. See, e.g., 1 AnNals of Cong. 804 (J. Gayles ed. 1789) (William Jackson arguing that state judges should "execute" Federal laws). The absence of such a definition has forced the Court to rely on the "traditional" tasks of courts when trying to discern the limits of judicial power. See, e.g., Mistretta v. United States, 109 S. Ct. 647, 650-51 (1989); Morrison, 108 S. Ct. at 2614 n. 20.

115. See M. Frankel \& G. Naftalis, The Grand Jury: An Insttrution on Trial 12-13 (1977).

116. See R. MORRIS, supra note 106 , at 491.

117. The absence of such a decision is especially telling when contrasted with the Court's relatively early decision to depart from colonial practice by precluding federal common law crimes. See supra note 84. 
ports the Morrison majority's conclusion on the executive nature of prosecution and its resultant decision to uphold the Ethics in Government Act.

\section{Conclusion}

A little over two hundred years ago the Framers came to the Constitutional Convention with a model of a primarily private system of criminal prosecution assisted by minor, local officials. If they left with a different model in mind, they neither recorded the discussions which led to this change, nor immediately institutionalized the new model in their federal system.

Most of the possible conclusions concerning the Framers' intent on the locus of the prosecutorial function are at best tentative. Given the limited importance of public prosecution at the time, the Framers may have viewed the locus of the prosecutorial function as a statutory, not a constitutional, question; given the quasi-judicial nature of contemporary public prosecutors, the Framers may have continued to see this as a minor, judicial function; or, given the independence of the local public prosecutor, the Framers may have viewed criminal prosecution as an executive-not a presidential-function. Only two conclusions appear more certain: The Framers intended that Congress would influence, but not conduct, prosecution; and the Framers did not view prosecution as a core executive, or presidential, function. The Ethics in Government Act is consistent with these more definitive conclusions, as is the Morrison majority's conclusion that prosecution is not a quintessentially executive function.

Yet the Framers' history alone should not guide the application of the Morrison decision. The proper answer to the question whether prosecution is intended to be, or has through practice become, a core executive function would require an analysis of prosecution throughout American constitutional history. Such an analysis would trace the developments over the past two centuries which have affected not only the nature of Federal prosecution, but the concept of "executive power" and the separation of powers doctrine. This history has witnessed the belated arrival of a Department of Justice, the explosion of Federal criminal prosecution, the expansion of administrative agencies with "executive," "legislative," and "judicial" functions, and the rise of an imperial presidency supported by a sprawling executive branch far beyond the reach of a cumbersome impeachment mechanism. If an examination of these later developments reinforces the ambiguous and shifting locus of the prosecutorial function found by this Note, the President should expect the Morrison analysis in cases involving an executive function with a similarly complex constitutional heritage-in short, cases involving an executive function typically undertaken by officials within the executive branch. 